\title{
The regulation of technology, and the technology of regulation
}

\author{
Jonathan B. Wiener*
}

Duke University School of Law, Box 90360, Durham, NC 27708, USA

\begin{abstract}
Regulation may inhibit or stimulate technological change. The relationship depends on the technology of regulation - the design and instrument choice of regulatory policy. This essay examines the history of economic and social regulations over the last three decades, the explanatory power of theories of regulatory politics, the choice of regulatory instruments, the assessment of regulatory impacts, and the influence of each of these on the innovation and diffusion of technology (and of regulation). It concludes with recommendations for the future of regulation and technology.

(C) 2004 Elsevier Ltd. All rights reserved.
\end{abstract}

Keywords: Regulation; Technology; Innovation; Diffusion; Risk

\section{Introduction}

Technology and regulation are often posed as adversaries. Technology symbolizes markets, enterprise, and growth, while regulation represents government, bureaucracy, and limits to growth. The modern regulatory era, beginning in the 1960s, has regularly pitted calls to restrain technological risk through regulation ${ }^{1}$ against the competing concern that regulation could unduly hobble new technology and progress. In the 1970s that debate focused on technologies such as nuclear power, supersonic transport, and food additives. Today the debate continues as fears of technologies such as electromagnetic fields, greenhouse gas emissions, and genetically modified foods spark new calls for precautionary regulation.

\footnotetext{
* Tel.: +1-919-613-7054; fax: +1-919-613-7231.

E-mail address: wiener@law.duke.edu (J.B. Wiener).

${ }^{1}$ A thoughtful example in this vein is Tribe [1]. Tribe chaired a national panel of experts studying the need to regulate the risks of technological change.
} 
To some extent, this conflict is inevitable. Over time and across countries, institutional factors such as regulation clearly have a major influence on the rate of technological change and thus on societal prosperity [2]. Technological change is generally credited with half or more of productivity growth [3: p. 171]. As Schumpeter argued, the process of "creative destruction" by entrepreneurs who devise new ways of producing goods and services is potentially a far more potent source of progress than is short-term price competition [4]. And regulation can retard all of Schumpeter's three stages of technological change: invention, innovation, and diffusion.

But the standard juxtaposition of regulation and technology has not gone unchallenged. First, many have argued that technological change itself can reduce risks by introducing superior new methods of production [5]. Among the evidence for this claim is the steady rise in life expectancies (almost doubling, from about 45 in 1900 to about 80 in 2000, in the US and most other wealthy countries) over the era of rapid technological advance. In more specific ways, newer products and devices are often less dangerous and less polluting than older ones, suggesting that regulation meant to reduce risks should not inhibit new technology. Second, some have hypothesized that regulation could improve, rather than inhibit, businesses' innovative edge and competitiveness [6]. In the stronger version of this hypothesis, regulation stimulates the firm to conserve resources and switch to cleaner substitutes in ways that actually save the firm money. In the weaker version, even if such moves are costly to the firm, regulation enables firms in countries that regulate first to take the lead in selling new technologies to countries that follow.

A fundamental weakness in all of these claims is the depiction of regulation as a single kind of rule or strategy. Regulation is treated as if it comes in one type and has only one effect on technology, like an engine transmission that can shift into only forward or reverse. In reality, just as there are many different types of technologies, there are many different types of regulations. Different regulatory instruments, such as technology requirements, performance standards, taxes, tradable allowances, and information disclosure, can have very different effects on technological change and other important consequences.

Indeed, if technology is understood in its broad sense-as not just hardware or equipment or sprockets or chips, but as any device or system for converting inputs into outputs, for changing the production function-then regulation is itself a technology. Regulation is a set of techniques for changing production functions to produce fewer of some outputs, such as pollution, or more of others. Regulation is the technology of governance. The terminology that regulatory scholars use to analyze regulation invokes this technological view: we speak of "instrument choice" as in medicine or music, of choosing "policy tools" from the "regulator's toolkit", and of "reinventing government" to achieve goals more successfully. The influence of regulation on technology is critically dependent on the technology of regulation. Different regulatory designs can impede or accelerate technological change, or shape it in varying ways, favoring some kinds of technology over others.

This essay highlights several of the most salient developments in US regulation over the last three decades and their effects on technological change. First, we have 
seen the widespread deregulation of economic regulation (price and entry controls on industries such as trucking, airlines, and banking), simultaneous with the explosive growth of social regulation (health, safety and environmental rules, also known as risk regulation). This change is ironic because it contradicts what had been the leading theory of regulatory politics, namely that concentrated industry groups would capture regulation and bend it to serve their own interests.

Second, over the last three decades, there has been a major shift in the debate over the design of social regulation from moralistic to pragmatic terms, with a concomitant rise in the use of incentive-based instruments such as tradable allowances. In the 1970s, much regulation required installation of specific technology, and a common objection to tradable allowances was that they amounted to "licensing the right to pollute". Today that debate has ended as environmentalists, industry and the public now focus on whether regulatory instruments effectively achieve risk reduction and at what cost. Ironically, the technology requirement approach turned out to be less effective at stimulating technological change than performance standards and tradable allowances.

Third, a major development over the past three decades has been the rise of governance by assessment: technology assessments to forecast the social and economic impacts of new technologies, and regulatory impact assessments (RIAs) to forecast the social and economic impacts of new regulations. These assessments are usually conducted ex ante, before the decision to adopt the new technology or regulation, and that is an important step. But we have had too little retrospective empirical investigation of the actual impacts in practice of alternative regulatory designs on important consequences such as health outcomes and technological change. Accordingly, we have cultivated too little regulatory innovation-Schumpeterian entrepreneurship in the public sector-to devise alternative regulatory designs, test them in practice, and thereby select the best performing approaches.

\section{The changing politics of regulation}

In the 1960s, the US federal regulatory regime was comprised mostly of economic regulation assembled over the preceding decades: price and entry controls on industries such as agriculture, energy, trucking, airlines, telecommunications, and banking. Apart from food and drug law, there was comparatively little federal social regulation of health, safety and environmental risks. With this history, it may not be surprising that the leading theory of regulation held that industry would dominate regulatory politics, lobbying for regulations to shield business profits and against regulations that would burden industry. The theory argued that political activism is costly, and that where the benefits of regulation are widely shared, individual beneficiaries will face strong incentives to free ride by letting others pay the costs; thus, regulations yielding public goods enjoyed by the general public (and imposing costs on concentrated interests) will go underprovided. But regulations yielding special benefits to concentrated groups will be more frequently 
adopted [7]. Further, because industry is wealthy and well-organized, it can be expected to dominate other special interests in this game, and regulation will largely serve industry's interests. ${ }^{2}$ This theory suggested that economic regulation would endure while social regulation remained dormant.

But the subsequent history of regulation does not fit this story. First, starting in the mid-1970s, economic regulations were repeatedly dismantled in a wave of deregulation. Antitrust enforcement targeted alleged monopolies in telecommunications and computing. Prominent examples include the deregulation of airlines, banking, and trucking, and the breakup of the AT\&T telephone monopoly. Economic deregulation was advocated and led by academics serving in government, including Alfred Kahn and Stephen Breyer; it proceeded aggressively during the Carter administration and had broad bipartisan support. ${ }^{3}$ The effects of economic deregulation on technological innovation are ambiguous; larger firms or those earning extra profits due to entry barriers may have more resources to invest in $\mathrm{R} \& \mathrm{D}$, but less competitive pressure to do so or to adopt new technology, whereas smaller firms in more competitive markets may have greater incentives to innovate but fewer resources. ${ }^{4}$ Meanwhile, the quasi-monopoly rights, such as patents and copyrights used to encourage technological innovation, have been strengthened in the last few decades, so much so that some critics now argue that intellectual property rights have become too strong and are barriers to a shared commons of ideas that undergirds collaborative innovation [12].

Second, an explosion of social regulation began around 1970. President Nixon organized the Environmental Protection Agency in 1970, and Congress enacted a string of powerful new laws, including the Clean Air Acts of 1970 and 1977, the Occupational Safety and Health Act of 1970, the Clean Water Act of 1972, the Endangered Species Act of 1973, the Toxic Substances Control Act of 1976, and the hazardous waste laws of 1976 and 1980.

These two waves remade the modern regulatory state into its present pattern of much diminished economic regulation and much invigorated social regulation. Ironically, this pattern and its evolution are the opposite of that predicted by the prevailing theory of regulation from the 1960s [13,14]. Perhaps it was impossible to predict these changes in the 1960s; it is always hard to see a revolution when one is in the middle of it. ${ }^{5}$ One possibility is that the 1960 s theory was just overdrawn, in the sense that political costs and free riding do explain the enduring predominance of special interest legislation over general interest legislation, but that industry

\footnotetext{
${ }^{2}$ The industry-capture hypothesis was espoused by scholars on the left, e.g., Kolko [8] and on the right, e.g., Stigler [9].

${ }^{3}$ See, for example, Niskanen, and Kearney and Merrill [10]. Economic deregulation has since spread worldwide. See Ref. [11].

${ }^{4}$ For an overview, see Council of Economic Advisors [3: pp. 173-193].

${ }^{5}$ Kahn and Wiener [15], who were otherwise prescient about manifold social trends, gave little attention to the coming environmental movement and the rise of social regulation. As early as 1974, scholars of regulatory politics began to observe that the rise of social regulation had not been well explained by the 1960s political theory. See Posner [16].
} 
alone does not dominate other special interest groups in the competition for political advantage. Yet it is difficult to attribute the wave of environmental legislation in the early 1970s to the influence of environmental and consumer advocacy special interest groups, because most of them had not yet formed at that time. $^{6}$

A second possibility is that the 1960s theory holds true in ordinary times, but that occasional "republican moments" (perhaps fueled by dramatic news events such as rivers burning and oil spills) galvanize broad public opinion and overcome special interest opposition [18]. That may be so, given the major social reform movements that arose in the 1960s, but it fails to explain why such republican moments occur only when they do, nor does it account easily for the continued growth of social regulation in the 1980s and 1990s.

A third possibility is that the 1960 s theory remains valid, on the view that the 1970s social regulation was actually driven by subgroups of industry to serve their own parochial advantage by raising rival firms' costs [19]. That may explain some key aspects of the new laws, but it fails to account for the origin of the broad new body of legislation that surely did burden industry.

A fourth possibility is a hybrid of the second and third: that an unusual but very potent coalition of environmentalist "Baptists" and industry "bootleggers" came together to secure the passage of new laws that both protected public health and provided parochial gains to one industry subgroup against another. ${ }^{7}$ This coalition theory is reinforced by the theory that political entrepreneurs saw openings to advance legislative agendas that would satisfy voters' inchoate but impending preferences. 8

These theories of the politics of regulation bear directly on the relationship of regulation to technological change. If the wave of 1970 s social regulation were simply industry capture or an environmentalist republican moment, its effects on technology might be positive or negative. But the Baptists and bootleggers coalition implies a regulatory design outcome that is more likely to retard technology. The Baptists in this story were the environmental movement, who saw growth, technology, capitalism, and markets as the enemy of ecology. The Limits to Growth school, the Club of Rome, the Small is Beautiful movement, the extreme Deep Ecologists, and related exponents were not merely pro-environment, they were often (especially at the extremes) decidedly anti-technology. To be sure, many environmentalists were sensible advocates of desirable restrictions on excessive pol-

\footnotetext{
${ }^{6}$ Moreover, if interest group politics are "limited to [industry], they are often inaccurate. They cannot fully explain environmental, health, [and] safety regulation... If the theory is expanded beyond producers, it risks becoming nonpredictive and nonexplanatory. All regulatory rules and programs benefit some group or other" Breyer [17].

${ }^{7}$ Yandle [20]. The theory of "Baptists and bootleggers" takes its name from Sunday liquor closing laws, which benefit both of these factions. For a critical review of these theories, see Wiener [21].

${ }^{8}$ On the ability of political entrepreneurs to appeal to voters' potential preferences, see Arnold [22] and Wilson [13: pp. 357, 370-371]. But such a strategy presupposes latent or rising public preferences, see Denzau and Munger, and Schroeder [23].
} 
lution, restrictions that would easily satisfy an economist's benefit-cost test; and some were advocates of forcing new more benign technologies. But many feared that technology and growth would yield "overshoot and collapse". They saw the environment as scarce and economic resources as vast (hence regulation is not costly).

The Bootleggers, meanwhile, were often the organized existing industry seeking to impose cost barriers to deter potential new entrants [24]. Much of the 1970s regulation took the form of special higher burdens imposed only on new sources: new source performance standards and new source review for factories and electric utilities, special restrictions on air pollution in the sunbelt, special controls on new automobiles, and extra restrictions on new chemicals and new pesticides. Thus, both Baptists and Bootleggers favored regulatory designs that impeded technological change.

The Limits to Growth movement was opposed by many, including brazen technological optimists who saw any restrictions as anathema, and more moderate critics who agreed that some risks were worth regulating but advocated regulatory designs that used economic incentives to be less costly and less inhibiting of innovation. The extreme technological optimists saw technology and growth as the solution to all problems, including environmental problems; they saw the environment as vast and the economy as scarce (hence regulation is quite costly).

Both of the extremes were wrong, because both neglected the crucial role of prices and institutions. If economic growth yields resource scarcity and if that scarcity is reflected in prices, then markets respond by conserving and finding substitutes; there is no collapse. Hence optimist Julian Simon won his famous bet with pessimist Paul Ehrlich because they bet on metals, which are priced in markets and avoided scarcity through price signals that motivated conservation, substitution, new exploration, and thus declining real prices. But if growth yields scarcity that is not reflected in prices (i.e., resource depletion that is external to markets), then markets will not respond, conservation and substitution will not occur, and serious depletion can occur. Thus, clean air, clean water, and biodiversity can be depleted by pollution and land clearing, with adverse effects that are not reflected in the prices of the depleting activities (externalities), with no incentive for markets to conserve or substitute. In short, there can be real market failures. Social regulation seeks to remedy such market failures by introducing incentives into markets to "internalize the externalities". If Ehrlich and Simon had bet on the "price" of clean air or biodiversity, then (apart from social regulation), Ehrlich might have won. Institutions matter: scarcities must be internalized into market transactions to induce desirable levels of resource use.

The coalition of Limits to Growth Baptists with existing industry Bootleggers is visible today in the coalition of environmentalists advocating the "Precautionary Principle" (requiring strict regulation of uncertain new technological risks) along with industry seeking protection against foreign competition or new entrants (such as foreign or new methods of genetically modified agriculture). Opponents of precaution argue that such restrictions will stifle technological change. But the mainstream view has moved toward the understanding that the key is whether 
institutions exist to internalize external social costs. The mainstream has thus embraced both the need to regulate important risks, and the need to do so in a way that avoids inhibiting growth and innovation, indeed attempts to stimulate innovation. That is the basic underpinning of "sustainable development", the vague but widely adopted term introduced in 1987 to reconcile environmental protection with economic development, and also of the economist's recipe for incentive-based regulatory instruments that cost-effectively reduce risks while encouraging flexibility and innovation.

\section{The choice among regulatory instruments}

During the growth of social regulation over the last 30 years, the debate over regulatory design has matured from moralistic to pragmatic. In the 1970s, a strong theme was the juxtaposition of good versus evil, of white hats versus black hats, and of the need to expiate the sin of pollution [25]. Economic incentive instruments such as taxes and tradable allowances were excoriated as "licensing the right to pollute". This mindset was of a piece with the social movement that saw capitalism and markets as the cause of pollution, and therefore rejected the economists' notion that markets could also be a solution. The result was a series of major laws and agency actions to rebuke markets, mandating instead that industry adhere to prescriptive conduct requirements, including requirements to install specific "best available control technology".

Over the last 30 years, there has been significant innovation in the choice of regulatory instruments. This has been reform of social regulation, not deregulation. Newer regulatory programs have introduced economic incentive instruments designed not to contradict market forces but rather to "reconstitute" markets by introducing price signals that internalize externalities, reduce pollution, and induce flexible, creative, innovative responses by firms [26]. From the initial generation of command-and-control technology requirements, regulatory design has graduated to setting performance standards (such as emissions limits that leave to the firm the choice of how to reduce emissions), emissions taxes, emissions allowance trading, and information disclosure rules.

The type of regulatory instrument matters [27]. Technology requirements, intended to force industry (or at least new and modifying sources) to upgrade, may foster the diffusion of existing technology across industry, but ironically may stagnate innovation of new technologies by specifying a particular technology and giving no incentives for further improvements [28]. Once scrubbers are mandated, firms have few incentives to invent a better method. Because the government is typically behind the curve of technology (compared to industry), and because regulations take years to promulgate and enforce, the "best technology" mandated by regulation may often be inferior to the best that industry could actually deploy. Moreover, imposing extra requirements on new sources encourages firms and motorists to keep older facilities and vehicles in operation longer, retarding the diffusion of new equipment and worsening pollution [24]. 
Performance standards encourage innovation by offering "how" flexibility - the flexibility to choose the methods of compliance. If the government mandates a maximum level of emissions, then firms may choose among, say, scrubbers, lowerpolluting materials and fuels, and alternative production methods, and they face continuing incentives to innovate and adopt new methods that reduce the cost of limiting emissions to meet the performance standard. ${ }^{9}$ Different types of performance standards matter: limits on absolute emissions may encourage reductions, while limits on the rate of emissions per unit of product output may perversely encourage increased output [29].

Taxes and tradable allowances offer "how" flexibility and an additional aspect: "where" flexibility, that is, the flexibility to locate emissions reductions where they are least costly. For example, assume the government wants to reduce pollution by two units from an industry of two firms, A and B, which currently emit three units each for a total of six. If the government requires a specific control technology designed to reduce emissions by one unit at each firm, that will cost each firm, say, US\$ 100 for a total of US\$ 200 and two units reduced. If the government sets a performance standard requiring each firm to reduce emissions by half to one unit, that will cost firm A the same US\$ 100 (it installs the same technology) but firm B only US\$ 20 (it has a cheaper option) for a total of US\$ 120 and two units reduced. $\mathrm{A}$ and $\mathrm{B}$ both now also have an incentive to find even cheaper new ways to avoid that unit of emissions. If the government instead issues each firm two allowances to emit, and makes these allowances tradable, then firm A will offer to pay firm B something over US\$ 20 (but under US\$ 100) to get B to sell one unit allowance to A (which will then own three allowances and emit three units), and reduce an extra unit at B (at B's cost of US\$ 20; B will then own one allowance and emit one unit). The result is a total cost of US\$ 40 and two units reduced. As this example illustrates, innovation in regulatory design from technology requirements to performance standards to allowance trading accomplishes the same aggregate emissions control (two units) ${ }^{10}$ at decreasing cost, from US\$ 200 to US\$ 120 to US\$ 40.

Tradable allowances have now been used successfully in a wide range of applications, including to phase lead out of gasoline in the 1980s; to phase out chlorofluorocarbons (CFCs) that deplete stratospheric ozone, pursuant to the 1987 Montreal Protocol; to cut sharply emissions of sulfur dioxide under the 1990 Clean Air Act acid rain program - at dramatic cost savings compared to nontrading

\footnotetext{
${ }^{9}$ Some argue that although technology requirements may be more costly and less innovation-friendly, they are easier to monitor than performance standards. Yet monitoring the installation of the technology is not the same as monitoring actual environmental performance; and the added costs of performance monitoring are often far outweighed by the benefits of performance standards over technology requirements. Moreover, this debate points out that well-designed performance standards can stimulate innovation in monitoring technologies, by offering greater credit for better-monitored emissions reductions.

${ }^{10}$ The example assumes equal benefits regardless of where the emissions reductions occur, as would be the case for a well-mixing pollutant with global but no local effects, such as carbon dioxide. Trading allowances of a pollutant posing local "hotspot" effects would require a more complex analysis. See Wiener [30].
} 
approaches; to limit harvests in depleted fisheries; and others. Soon tradable allowances may be used to reduce emissions of greenhouse gases. ${ }^{11}$

Taxes have been used less often in the US, but more often in Europe [32]. Meanwhile, another incentive-based instrument, information disclosure, has been used widely, including to make government decisions more transparent (through the freedom of information and environmental impact statement laws), to reveal and reduce releases of toxic substances (through the Toxics Release Inventory), and to publicize workplace risks (through OSHA's hazard communications standard). In addition to the innovation of these new technologies of regulation, there has been considerable diffusion as well, with countries borrowing approaches from each other to apply to similar and even different problems [33: p. 1295; 34].

Why did this reform occur? Industry might be expected to lobby against incentive-based approaches because taxes and tradable allowances force firms to pay for every unit of emissions (by controlling some emissions and paying the tax, or foregoing the allowance sale revenue, on the remaining uncontrolled emissions), whereas technology requirements and performance standards put no cost on the residual uncontrolled emissions they permit [35]. And in the past, many environmentalists opposed tradable allowances as an immoral license to pollute. But the rising costs of rigid regulation, the cost-saving rewards of incentive-based approaches (including the ability to "buy" more pollution control at the same or lower cost), the efforts of EPA staff and White House leadership to innovate cost-saving flexibility, the efforts of policy entrepreneurs such as the pro-incentive group Environmental Defense (and, in the case of acid rain, the fortuitous shift of political leadership in the Senate from Robert Byrd of West Virginia to George Mitchell of Maine), all combined to shift regulatory politics toward increasing use of incentive-based regulations [36].

In the wake of this trend and the success of tradable allowance systems in practice, one almost never hears the old epithet about "licensing the right to pollute". Of course that accusation never stood up, because traditional technology requirements and performance standards also licensed the right to emit the permitted level, and for free, whereas tradable allowances and taxes make the firm pay for every unit of emissions. The evolution from the old moralistic debate to the current pragmatic debate marks a healthy maturation of regulatory policy. Regulatory design should be about consequences-what works, how much, with what costs and side effects. Ironically, if the moralistic contention is that those who stand in the way of pollution reduction are immoral, and if incentive-based approaches are more effective in reducing pollution (such as by stimulating greater technological innovation), then those who on moralistic grounds advocate cumbersome

\footnotetext{
${ }^{11}$ Stewart and Wiener [31]. An important new area of research on regulatory design investigates how the optimal instrument choice depends on the underlying legal framework, such as the voting rule for the adoption of policy. Under majority rule, instrument choice can be imposed on dissenters. But under policy adoption by consent, as is the rule for international treaties, then important dissenters (e.g., China or even the US) must be attracted to participate via side payments, which must be compatible with the regulatory instrument. See Wiener [27].
} 
command-and-control regulation and reject incentive-based regulations are committing their own $\sin ^{12}$

It is clear that the move from technology requirements to either performance standards or tradable allowances improves the incentives for technological innovation by offering "how" flexibility. More innovation is achieved by requiring results, not by requiring installation of a specific recent innovation. There remains, though, some debate whether tradable allowances stimulate innovation as compared to uniform performance standards without trading. Incentive-based taxes and tradable allowances promote dynamic innovation and diffusion because they give sources a continuous incentive to improve abatement methods [38]. Every unit of uncontrolled emissions is a cost to the firm in extra taxes or allowance sale revenues foregone. Sources can increase their profits by devising or adopting new abatement methods that are less costly than the expected cost of paying the tax or allowance price. But critics argue that emissions trading does not promote innovation, compared to a performance standard set to achieve the same aggregate reduction (and assuming allowances were issued for free), because under trading the high-cost firms will undercontrol while the low-cost firms will overcontrol, so the net effect on innovation is a wash, or emissions trading is even worse because it lowers costs and that reduces the incentives to innovate (presuming that innovation is driven by higher costs of abatement) [39]. But this argument neglects the incentive under emissions trading for all firms to avoid the costs of buying allowances by devising more cost-effective methods to control than their competitors; all firms compete to overcontrol and sell allowances, because every uncontrolled unit represents a cost of foregone allowance sale revenue - an incentive not provided by uniform performance standards. Ultimately, we need empirical comparisons of these instruments in practice. ${ }^{13}$ And, of course, innovation is not per se desirable; there can be excessive investments in innovation. If emissions trading dampens incentives for innovation at high-cost firms by allowing them to finance abatement at lowcost firms, thereby reducing overall costs compared to a fixed performance standard, that means trading reduces total costs, which is socially desirable. Requiring high-cost firms to spend on innovation would just raise total costs for the same pollution control result. ${ }^{14}$

\footnotetext{
${ }^{12}$ Wiener [27: pp. 723-25]. A similar point is made by Rose [37].

${ }^{13}$ Some empirical evidence favors the view that emissions trading stimulates more innovation than would equally stringent performance standards [40].

${ }^{14}$ Another question is whether taxes and tradable allowances have differing influences on innovation. In principle they can be set to have identical effects. But emissions trading may stimulate more optimal innovation under uncertainty about costs. See Gruenspecht and Lave [41]. The logic is that if investment in innovation is driven by the volume of abatement activity to which it can be applied, a tax that yields overcontrol of emissions (because true abatement costs are lower than expected costs) will induce overinvestment in innovation, which further reduces abatement costs and further compounds the degree of overcontrol. A tax that yields undercontrol of emissions (because true abatement costs are higher than expected costs) will induce under-investment in innovation, which keeps abatement costs high and compounds the problem of undercontrol. An emissions quantity rule, by contrast, fixes the level of abatement and thus induces closer to optimal investment in innovation, with no perverse feedback effects.
} 
The foregoing enables a more sophisticated response to the debate noted at the beginning of this essay over whether regulation inhibits or stimulates technological innovation. In its stronger form, the Porter hypothesis states that regulation promotes the adoption of newer cost-saving technology [6]. But if so, then one wonders why firms do not adopt it anyway; what is the market failure? Possible answers include internal gaps in the accounting of costs within the firm [42], and spillover benefits or economies of scale that discourage one firm from adopting a new technology unless other firms do as well [3: p. 200; 43]. But studies finding cost-saving in terms of material inputs (e.g., reduced energy costs) may be omitting the opportunity costs of other technologies foregone and of managerial time used to devise the method to comply with the pollution regulation instead of pursuing other opportunities. The empirical evidence indicates little support for the strong form of the hypothesis $[44,45]$. In its weaker form, the Porter hypothesis concedes that regulation is costly, but urges that first-adopters can gain a competitive advantage over second-adopters when regulation in the first country is imitated by other countries. The validity of this effect depends on other countries imitating the firstadopter quickly enough to stimulate demand to enable the first-adopter to recoup its costs plus more, while not so quickly that the second-adopters could take the first-adopter's market share.

Moreover, the incentive to adopt new technology depends importantly on the type of regulation. If the initial regulation is technology-specific, then the incentive to adopt the cost-saving technology may be missed; if the initial regulation is technology-specific, and the second-adopter countries do not require the same technology, then the first-adopter advantage may be lost. Regulations offering "how" flexibility, such as performance standards, taxes, and tradable allowances, will therefore all be much more effective in achieving the gains promised by the Porter hypothesis than technology requirements.

\section{Regulatory impact assessments and outcomes}

The growth of social regulation since the 1970s has motivated a parallel increase in White House review of such regulation. Every president since Jimmy Carter has ordered an economic analysis of new agency regulations: President Carter issued Executive Order (EO) 12044, President Reagan issued EO 12291, and President Clinton issued EO 12866. The Reagan order required every new regulation to be accompanied by an RIA that evaluated the rule's benefits and costs, and it designated the Office of Information and Regulatory Affairs (OIRA) within the Office of Management and Budget (OMB) as the body to review RIAs. The Clinton order reiterated the benefit-cost test (while changing its terms from benefits must "outweigh" costs to benefits must "justify" costs), and added instructions to evaluate the adverse side effects of regulations on health and environment; to assess qualitative and distributional impacts; and to ensure the transparency of OIRA review. The current Bush administration is continuing to operate under the Clinton order, indicating bipartisan continuity on the parameters of executive branch review. 
The process of executive review reflects the recognition that the technology of regulation, like any technology, may have complex multidimensional impacts. Just as any new technology may have unintended consequences, so may new regulations. OIRA review helps identify such consequences and ensure a thorough, coherent analysis before the regulation is deployed [46]. Yet, to date, this analysis has been more successful in assessing the short-term costs and benefits of regulation than it has in forecasting long-run impacts on technological change.

Apart from costs, an important concern is that regulations intended to reduce one risk may induce other countervailing risks or reduce additional ancillary risks [47]. To cite a few examples, medicines (from aspirin to vaccines) have adverse side effects; banning one chemical may introduce harmful substitutes; airbags in cars may save adults but kill children; reducing fossil fuel combustion may increase reliance on nuclear energy; police chases to catch fleeing suspects may kill bystanders. Each regulatory intervention creates a vector of effects, a portfolio of ripples. Countervailing risks are not just an automatic homeostatic or gremlin-like reactions to efforts at progress. ${ }^{15}$ Rather, they arise from narrow interventions into the real world of complex systems and interconnected webs, with multiple effects. Narrow regulatory designs exacerbate such tradeoffs; more comprehensive regulation can internalize what would otherwise be regulatory externalities. In this respect, regulatory instruments are like medicine: a technology for healing that can also hurt [50]. Responsible physicians, patients, regulators, and the public must weigh such tradeoffs. Ultimately, recognition of such complexity helps to motivate the search for risk-superior options - innovations in the technology of regulation that reduce multiple risks in concert. Examples include the 1990 Clean Air Act $\S 612$, which provides for CFC substitutes to be regulated to reduce their "overall risk", including effects on ozone depletion, global warming, toxicity, and other impacts; and the 1996 Safe Drinking Water Act amendment authorizing the EPA to weigh risk tradeoffs where reducing one water contaminant could increase others and to adopt standards that minimize "overall risk". Often such risk-risk analyses and risk-superior regulatory innovations will in turn stimulate innovations in private technology, such as "smart" air bags that deploy more softly at smaller occupants, or vaccines with fewer side effects.

Risk regulation may now be at a stage of understanding similar to medicine in the 19th or early 20th century, when it was still debatable whether medical treatment did more good than harm. ${ }^{16}$ Early medical care often did net harm (as it still does sometimes today) [50]. The objective should be innovations in regulatory design that progressively increase the net good they accomplish.

\footnotetext{
${ }^{15}$ For such a view, see Tenner [48]. For a critique of such claims of automatic perversity, see Hirschman [49].

${ }^{16}$ The political scientist Russell Hardin cites John Mueller for the view that economics has reached the point that it may now generally be helpful to governmental economic policymakers, just as the Flexner Report of the American Medical Association concluded that around the beginning of the 20th century, going to an American doctor finally was more likely to benefit people who were ill than to harm them. See Hardin [51], citing Flexner and Mueller [52].
} 


\section{Future directions}

The influence of regulation on technology is complex, and depends on the technology of regulation - the design and instrument choice of the regulatory intervention. After the last three decades of regulatory experience, we are poised to make additional progress, but several issues need to be addressed.

First, we need to cultivate policy entrepreneurs. Just as Schumpeter highlighted the pivotal role of private entrepreneurship (and there is a growing movement of social entrepreneurship [53]), we need to stimulate policy entrepreneurs - not just political entrepreneurs who seize opportunities to advance agendas, ${ }^{17}$ but policy innovators who will develop and test new forms and approaches to regulation for greater effectiveness, less cost, less caustic side effects, and other desirable attributes [54]. The study of policy innovation starts from the proposition that there is no single universal best policy design, or best regulatory technology. Instead there are contextual criteria for success, which imply different regulatory designs for different problems, situations, societies, and institutional settings. We must test policy ideas, learn from empiricism, and adapt regulatory technology over time.

Second, we should build on the experience with tradable allowance systems to see the more general lesson-that reconstituting markets by creating "regulatory property" can be a highly successful antidote to failures in private property markets. Both economic and social regulations are responses to market failures: inadequate property rights undermining the incentive to invest in innovation; excessive property rights creating barriers to entry and monopoly profits; inadequate rights to exclude pollution and depletion leading to the "tragedy of the commons". Attempts to remedy these property rights failures via centralized command regulation have also failed, whether in the former USSR, or in American central government economic regulation, or American centralized social regulation. But that does not mean that there is no role for central government. The lesson is to move toward internalizing externalities by reconstituting markets through new "regprop" such as tradable allowances as well as information instruments and other creative new approaches [55].

Third, we must recognize that regulatory interventions operate in an ecological system, by which I mean not just the ecology that some laws aim to protect but the larger interconnected web of nodes and strands into which regulation seeks to introduce change. That change is inevitably multi-dimensional. Insistence on narrow regulations triggered by emerging risks, such as strong versions of the Precautionary Principle, will founder amidst this complexity [56]. If the Precautionary Principle means (as some versions state) that any new technology must be blocked until its proponents demonstrate that it poses no risk or is safe, then the recognition that regulation itself is a technology, and poses potential countervailing

\footnotetext{
${ }^{17}$ As noted by Schumpeter [4: pp. 269-270] (emphasizing the "vital fact of leadership" in democracy); also at p. 282 (political leaders are entrepreneurs who shape public preferences). Also, Wilson [13: pp. 370-371].
} 
risks, means that the Precautionary Principle would swallow itself. The solution to this paradox is a multi-risk portfolio approach and risk-superior solutions.

Fourth, we should foster networks for the diffusion of regulatory innovations. Just as private technology diffusion is crucial to economic prosperity, so the diffusion of improved public regulatory technology is crucial to social progress.

Fifth, the experience of the last three decades, and its contradiction of the leading theory of regulatory politics at the outset of this era, should make us circumspect about our current theories of regulatory politics. Our current explanatory theories may do better at predicting the last decades than the next. We may soon need a new theory to explain unexpected developments yet to come.

Sixth, a key frontier for regulation and technology is the global commons. If we are to have any success in addressing problems such as global climate change, the engagement of major developing countries will be essential. A key challenge for the new technology of regulation will be to engage developing countries in producing global public goods without coercion. And the global stage will also be crucial for the innovation and diffusion of new private technologies, such as lower greenhouse-emitting energy technologies for rapidly developing economies. Ideally, these two challenges will dovetail: new regulatory approaches will engage major developing countries in part by promising a flow of technological innovations.

Seventh, we must become more regular empiricists about our regulatory designs. Does regulation inhibit or stimulate technological change? How does that depend on the technology of regulation? We have deployed regulation for three decades with increasing ex ante analysis of its predicted impacts, but too little ex post analysis of its actual impacts. The field of empirical retrospective analysis of regulatory impacts is in some ways just beginning [40,44,57]. We need far more work in this area, to study the multidimensional consequences of regulation, what works, how much, at what cost, with what side effects, compared to what alternatives. In turn, this retrospective analysis should help us revise our methods of ex ante predictions of new regulations.

Most generally, we need to develop an institutional structure that rewards policy innovation [58]. In the case of private-sector technology, we typically reward innovation through financial incentives, either by conferring quasi-monopoly intellectual property rights on inventors or by paying bounties to award-winning ideas. Whether these kinds of reward systems can be usefully applied to motivate publicsector policy innovation is far from clear. Conferring property rights in legal innovations-regprop for new regprop, as it were-poses immediate problems of restricting public access to new legal ideas, private sales of new legal ideas, the distribution of such rights (to academics? to judges?), and excessive incentives to overproduce new law. ${ }^{18}$ If these reward systems are deemed inappropriate, the question must be, compared to what alternative? That is, we will need to promote

\footnotetext{
${ }^{18}$ Wiener [33: pp. 1369-71] (discussing pros and cons of property rights in legal rules to encourage policy innovation); Ayres [59] (the idea of giving intellectual property protection to true innovations in regulation "should not provoke such a visceral gag reflex").
} 
innovation in the reward system used to promote innovation in regulatory design (which in turn should promote private-sector technological innovation). That multi-tiered set of incentives for innovation poses an apt challenge for the next three decades of regulation and technology.

\section{References}

[1] Tribe L. Channeling technology through law. Harvard Law School; 1973.

[2] North D. Institutions, institutional change, and economic performance. Cambridge: Cambridge University Press; 1990.

[3] Council of Economic Advisors. Economic Report of the President. Washington, DC: GPA; 1999. p. 171, 200, 173-93.

[4] Schumpeter JA. Capitalism, socialism and democracy (1942). London: Unwin; 1987.

[5] OECD. Innovation and the environment, 2000.

[6] Porter ME. America's green strategy. Sci Am 1991;April:168; Porter M, van der Linde C. Toward a concept of the environment-competitiveness relationship. J Econ Perspect 1995;9(4):97-118.

[7] Olson M. The logic of collective action. Cambridge, MA: Harvard University Press; 1971.

[8] Kolko G. Railroads and regulation 1877-1916. New York: Norton; 1965.

[9] Stigler G. The theory of economic regulation. Bell J Econ 1971;2(1).

[10] Niskanen WA. A retrospective. Regul Mag 2002;Summer:4-5; Kearney JD, Merrill TW. The great transformation of regulated industries law. Columbia Law Rev 1998;98(1323):1329-63.

[11] Yergin D, Stanislaw J. The commanding heights: the battle between government and the marketplace that is remaking the modern world. New York: Simon \& Shuster; 1998.

[12] Boyle J. Shamans, software and spleens: law and construction of the information society. Cambridge: Harvard University Press; 1996; Boyle J. The second enclosure movement and the construction of the public domain. Law Contemp Probl 2003;66:33.

[13] Wilson JQ. The politics of regulation. In: Wilson JQ, editor. The politics of regulation. New York: Basic Books; 1980, p. 357.

[14] Schuck PH. The politics of regulation. Yale Law J 1981;90:702; Horwitz R. The irony of regulatory reform. Oxford: Oxford University Press; 1989.

[15] Kahn H, Wiener AJ. The year 2000: a framework for speculation. New York: Macmillan; 1967.

[16] Posner RA. Theories of economic regulation. Bell J Econ Manage Sci 1974;5:325.

[17] Breyer SG. Regulation and its reform. Cambridge, MA: Harvard University Press; 1982, p. 388; Mashaw JL. Greed, chaos and governance. New Haven, CT: Yale University Press; 1997, p. 203 [criticizing public choice theory for the fallacy of "post hoc, ergo propter hoc" inferences].

[18] Pope JG. Republican moments: the role of direct popular power in the American constitutional order. Univ Pa Law Rev 1990;139:287; Farber DA. Politics and procedure in environmental law. J Law Econ Org 1992;8:60.

[19] See, for example, the following: Ackerman BA, Hassler WT. Clean coal/dirty air. New Haven, CT: Yale University Press; 1981. p. 31 [arguing that the scrubber requirements in the 1977 Clean Air Act protected eastern coal at the expense of western coall; Bartel AP, Thomas LG. Predation through regulation: the wage and profit effects of the Occupational Safety and Health Administration and the Environmental Protection Agency. J Law Econ;30:239 [arguing that OSHA and EPA regulations protected large firms and rust-belt firms against smaller firms and sun-belt firms]; Elliott ED, Ackerman BA, Millian JC. Toward a theory of statutory evolution: the federalization of environmental law. J Law Econ Org 1985;1:313 [arguing that the 1970 Clean Air Act protected the coal and automobile industries against patchwork state regulations]; Pashigian BP. Environmental regulation: whose self-interests are being protected?. Econ Inquiry 1985;23:55 [arguing that the "prevention of significant deterioration" (PSD) provision in 1977 Clean Air Act was adopted by rustbelt states over the dissenting votes of sunbelt states, in order to suppress economic growth in, and industry relocation to, the sunbelt]. 
[20] Yandle B. Bootleggers and Baptists in the market for regulation. In: Shogren JF, editor. The political economy of government regulation. New York: Kluwer; 1989, p. $29-54$.

[21] Wiener JB. On the political economy of global environmental regulation. Georgetown Law J 1999;87:749.

[22] Arnold RD. The logic of congressional action. New Haven, CT: Yale University Press; 1990.

[23] Denzau AT, Munger MC. Legislators and Interest Groups: how unorganized interests get represented. Am Poli Sci Rev 1986;80:89; Schroeder CH. Rational choice versus republican moment explanations for environmental laws, 1969-71. Duke Environ Law Policy Forum 1998;9:29.

[24] Gruenspecht HK. Differentiated regulation: the case of automobiles. Am Econ Rev 1982;71:328 [explaining preference of existing industry for restrictions on new sources].

[25] Margolis H. Dealing with risk. Chicago: University of Chicago Press; 1996, p. 25.

[26] Stewart RB. Reconstitutive law. Md Law Rev 1986;46:86.

[27] Wiener JB. Global environmental regulation: instrument choice in legal context. Yale Law J 1999;108:677.

[28] Breyer S. Regulation and its reform. Cambridge, MA: Harvard University Press; 1982, p. 105.

[29] Helfand GE. Standards versus standards: the effects of different pollution restrictions. Am Econ Rev 1991;81:622.

[30] Wiener JB. Hormesis, hotspots, and emissions trading. Biological Effects of Low-Level Exposures, Newsletters 2004;12(1):20-31.

[31] Stewart RB, Wiener JB. Reconstructing climate policy: beyond Kyoto. Washington, DC: AEI Press; 2003.

[32] Andersen MS. Governance by green taxes. Manchester: Manchester University Press; 1994.

[33] Wiener JB. Something borrowed for something blue: legal transplants and the evolution of global environmental law. Ecology Law Q 2001;27:1295.

[34] Wiener JB. Whose precaution after all? Duke J Comp Int Law 2003;13:207.

[35] Buchanan JB, Tullock G. Polluters' profits and political response: direct controls versus taxes. Am Econ Rev 1975;65:139-41.

[36] Joskow PL, Schmalensee R. The political economy of market-based environmental policy: the US acid rain program. J Law Econ 1998;41:37; Keohane NO, Revesz RL, Stavins RN. The choice of regulatory instruments in environmental policy. Harvard Environ Law Rev 1998;22:313.

[37] Rose CM. Scientific innovation and environmental protection: some ethical considerations. Environ Law 2002;32:755.

[38] Jaffe A, Stavins RN. Dynamic incentives of environmental regulations: the effects of alternative policy instruments on technology diffusion. J Environ Econ Manage 1995;29:43; Magat WA. The effects of environmental regulation on innovation. Law Contemp Probl 1979; Winter-Spring:4; Milliman SR, Prince R. Firm incentives to promote technological change in pollution control. J Environ Econ Manage 1989;17:247; Stewart RB. Regulation, innovation, and administrative law: a conceptual framework. Calif Law Rev 1981;69:1256.

[39] Driesen D. Does emissions trading encourage innovation? Environmental Law Reporter, January 2003; Malueg DA. Emission credit trading and the incentive to adopt new pollution abatement technology. J Environ Econ Manage 1989;16:52-7.

[40] Newell R. Environmental policy and technological change. Ph.D. Thesis. Kennedy School of Government, Harvard University; 1997; Popp D. Pollution Control Innovations and the Clean Air Act of 1990. J Policy Analysis \& Management 2003;22:641.

[41] Gruenspecht HK, Lave LB. The economics of health, safety, and environmental regulation. In: Schmalensee R, Willig RD, editors. Handbook of industrial organization. New York: Elsevier; 1507, p. 1507.

[42] Schmutzler A. Environmental regulations and managerial myopia. Environ Resour Econ 2001;18:87-100.

[43] Osang T, Nandy A. Environmental regulation of polluting firms: Porter's hypothesis revisited. Draft, Southern Methodist University, August 2003. Available from: www.faculty.smu.edu/tosang/ pdf/regln0803.pdf; Greater M. New hope for the Porter hypothesis? Draft, Statistics Norway, Oslo, 2003. 
[44] Jaffe AB, Newell RG, Stavins RN. Technological change and the environment. In: Maler KG, Vincent J, editors. The handbook of environmental economics. Amsterdam: Elsevier Science; 2003.

[45] Jaffe AB, Palmer K. Environmental regulation and innovation: a panel data study. Rev Econ Stat 1997;79:610-9; Palmer K, Oates W, Portney P. Tightening environmental standards: the benefitcost or the no-cost paradigm. J Econ Perspect 1995;9:119-32; Snyder L, Miller N, Stavins R. The effects of environmental regulation on technology diffusion: the case of chlorine manufacturing. RFF Discussion Paper, 03-25 August 2003.

[46] Sunstein CR. Cognition and cost-benefit analysis. J Legal Stud 2000;29:1059-103.

[47] Graham JD, Wiener JB. Risk vs. risk: tradeoffs in protecting health and the environment. Cambridge, MA: Harvard University Press; 1995.

[48] Tenner E. Why things bite back. Cambridge, MA: Harvard University Press; 1993.

[49] Hirschman AO. The rhetoric of reaction. Cambridge, MA: Harvard University Press; 1991.

[50] Wiener JB. Managing the iatrogenic risks of risk management. Risk Environ Health Saf 1998;9: 39-84; Weiler P. A measure of malpractice. Cambridge, MA; Harvard University Press, 1993.

[51] Hardin R. Whither political science? 2003. Available from: http://staging.denison.edu/ djupe/ POSC212_F03/Hardin.html.

[52] Flexner A. Medical education in the United States and Canada: a report to the Carnegie foundation for the advancement of teaching. Introduction by Henry Pritchett, Bull. No. 4. New York: Carnegie Foundation for the Advancement of Teaching; 1910.; Mueller J. Capitalism, democracy, and Ralph's pretty good grocery. Princeton, NJ: Princeton University Press; 1999.

[53] Borenstein D. How to change the world: social entrepreneurs and the power of new ideas. Oxford: Oxford University Press; 2003.

[54] Ostrom E. Public entrepreneurship: a case study in ground water basin management. Ph.D. Dissertation, University of California-Los Angeles; 1965.; Thompson VA. Bureaucracy and innovation. Tuscaloosa: University of Alabama Press; 1969; Carpenter DP. The forging of bureaucratic autonomy: reputation, networks, and policy innovation in executive agencies, 1862-1928. Princeton, NJ: Princeton University Press; 2001.

[55] Rose CM. The several futures of property: of cyberspace and folktales, emission trades and ecosystems. Minn Law Rev 1998;83:129; Stewart RB. Privprop, regprop, and beyond. Harvard J Law Public Policy 1990;13:91.

[56] Wiener JB. Precaution in a multi-risk world. In: Paustenbach D, editor. Human and ecological risk assessment: theory and practice. New York: John Wiley \& Sons; 2002.

[57] Harrington W, Morgenstern RD, Nelson P. On the accuracy of regulatory cost estimates. J Policy Anal Manage 2000;19:297-322; Hammitt JK. Are the costs of proposed environmental regulations overestimated? Evidence from the CFC phaseout. Environ Resour Econ 2000;16:281-301; Kolp PW, Viscusi WK. Uncertainty in risk analysis: a retrospective assessment of the OSHA cotton dust standard. Adv Appl Micro-Econ 1986;4:105-30.

[58] Duffy J. The FCC and the patent system: progressive ambitions, Jacksonian realism, and the technology of regulation. Univ Colorado Law Rev 2000;71:1072 ["But we may also hope, with cautious audacity, for something more-for progress not only in the bits and bytes of communications technology, but also in the technology of regulation. The challenge for the new century will be not simply to create better regulatory structures, but to create a regulatory superstructure that encourages the betterment of regulatory technology itself.'].

[59] Ayres A. Supply-side inefficiencies and competitive federalism: lessons from patents, yachting, and bluebooks. In: Bratton W, et al., editors. International regulatory competition and coordination: perspectives on economic regulation in Europe and the United States. Oxford: Oxford University Press; 1993, p. 239.

Jonathan B. Wiener is Professor of Law, of Environmental Policy, and of Public Policy Studies at Duke University, and Faculty Director of the Duke Center for Environmental Solutions. He is also a University Fellow of Resources for the Future (RFF), and in 1999, a visiting professor at Harvard Law School. In 2003, he received the Chauncey Starr Young Risk Analyst Award from the Society for Risk Analysis (SRA) for the best work in the field by a scholar age 40 or under. He has written widely on US 
and international environmental law and risk regulation, including more than 40 articles and books, including Reconstructing Climate Policy (AEI Press 2003, with Richard B. Stewart) and Risk vs. Risk (Harvard University Press 1995, with John D. Graham). Before coming to Duke in 1994, Wiener served in both the first Bush and Clinton administrations, as senior staff economist at the White House Council of Economic Advisers, as policy counsel at the White House Office of Science \& Technology Policy, and as special assistant to the head of the Justice Department's Environment Division. Wiener clerked for Judge (now US Supreme Court Justice) Stephen G. Breyer on the US Court of Appeals in Boston in 1988-1989, and for Chief Judge Jack B. Weinstein on the US District Court in New York in 1987-1988. He received his A.B. in Economics (1984) and his J.D. (1987) from Harvard University, where he was an editor of the Harvard Law Review and helped coach the 1985 intercollegiate debate champions. 